\title{
The concept of "justice" in the legislation of Russia and France, implementation features
}

\author{
Vera Borshcheniuk ${ }^{1}$, Nina Semeryanova ${ }^{1}$, Uliana Filatova $^{2}$, and Valeriy Zhabskiy ${ }^{3 *}$ \\ ${ }^{1}$ South Ural State University, 628600, 9, Mira str., Chelyabinsk, Russia \\ ${ }^{2}$ Irkutsk State University, 664003, 1, Karl Marx str., Irkutsk, Russia \\ ${ }^{3}$ Moscow University of the Ministry of Internal Affairs of the Russian Federation named after V.Y. \\ Kikot, 117437, 12, Academician Volgin str., Moscow, Russia
}

\begin{abstract}
The relevance of the study is determined by the prevailing variety of approaches to understanding the essence of the concept of "justice", which is characteristic of both Russia and France. Such variability leads to a persistent distortion of this concept in practice of law enforcement, which, in turn, affects the effectiveness of administration of justice. The aim of the authors is to study scientific theoretical views and practical issues associated with the implementation of the principle of justice in two states. In the work we used following methods: dialectics, analysis, synthesis, deduction, as well as the formal legal and comparative legal method.Based on the analysis of the doctrine, legislation and judicial practice of two states, Russia and France, the following conclusions are drawn. At present, "justice" is understood as a universal notion, which is not limited only by coverage of regulatory norms of the law, but is actively applied by judicial practice. The use of this concept allows the court to make fair decisions depending on specific circumstances of the case, thereby achieving a balance of interests of participants in the process by interpreting and clarifying the law, and in some cases by creating a new rule of law that allows the courts to ensure the effective implementation of the principle of justice. However, in order to avoid variability in understanding this notion, it is proposed to fix the concept of "justice" in the civil procedure code, this will reduce the percentage of judicial conflicts and will contribute to formation of a uniform judicial practice.
\end{abstract}

\section{Introduction}

The 21st century is characterized by rapid scientific and technological progress, contributing to a large-scale change in social relations and public outlook. Advanced ideas come to life, thereby changing the socio-economic order in society. The legislators are actively working on regulation of new relations, carrying out reforms in most branches of law. New trends challenge scientists to comprehend justice as a general regulator of social relations, where justice appears to be an incentive for the effectiveness of human development.

*Corresponding author: a.copytowa@yandex.ru 


\section{Review of research literature}

Justice is a multidimensional and controversial notion. It is the subject of research in various humanities (philosophy, psychology, sociology, political science, economics, law). The idea of justice was pondered by Plato, Aristotle, F. Bacon, I. Bentham, M. Sandel and others.

Particularly noteworthy is the work of the philosopher-political scientist John Rawls, "Theory of Justice," where justice is seen as a socio-political category and expressed in honesty in fulfilling its obligations. Thus, in the author's opinion, a particular practice should be declared fair if it complies with the principles, which promotion and adoption would be reasonable to expect from all participants, if they were in the same circumstances and had to take firm commitments in advance, without knowing what will be the special conditions they will find themselves in the future [1]. However, D. Rawls does not consider justice as a legal category, law in his understanding is only a phenomenon that formalizes justice [1].

In Russia, such scholars dealt with issues of correlation of the category of justice with the main categories of ethics as V.S. Soloviev, O.G. Drobnitsky, E.L. Dubko, A.P. Butenko et al. In the field of law this issue was discussed in the works of G.F. Shershenevich, L.I. Petrazhitsky, S.S. Alekseev, I.V. Chechelnitsky, I.I. Andrianovskaya, V.A. Waipan et al.

G.F. Shershenevich analyzed relations of sense of law and justice, L.I. Petrazhitsky studied the ratio of justice and law-making. S.S. Alekseev believed that justice is acquiring significance of a legal principle to the extent that it is embodied in the regulatory method of regulation, in those principles of proportionality, equality, etc., which are inherent in the very construction of a legal doctrine. A. Vaipan understands justice as universal measure and criterion of human behavior and understanding of the world, moral foundation and means of ensuring law and lawmaking. Any scientific discussion, the author believes, addresses issues of justice (distribution of income and property, taxes, punishment, redress, etc.), without understanding and applying the principle of justice, complex general legal problems of legal understanding, legal awareness, law-making and law enforcement are not solved.

Among French scholars who studied the category of justice, one can distinguish S.-L. Montesquieu, J.-J. Russo, L. Boltanski, L. Theveno, J. Ranciere, A. Badiou, S.-K. Colm As A. Badiu correctly notes, at present a special place is occupied by philosophical thought, which makes up a single knot with a political condition. He criticizes modern understanding of democracy; people, he believes, do not strive at all to be virtuous, their private interests clash, the principles of political truth are distorted. This creates new conditions for a philosophy whose goal is to achieve justice [2].

Undoubtedly justice is a moral category that is inherent in both politics and law. The idea of justice has always occupied a special place in the system of human values and has become a fundamental category in the legal consciousness of society. The very Latin origin of the term justice (justicia) consists of the words "law and justice", and lawyers (judges) are its representatives.

The purpose of the work is to search for meanings and mechanisms for understanding the legal essence of the category of "justice", to actualize the problematic issues that have arisen during implementation of principle of justice in Russia and France.

The novelty of the study lies in formulation, justification and solution of problems aimed at determining the essence of the category of "justice", comprehensive study of this category in the legislation and judicial practice of Russia and France. 


\section{Methods}

Dialectics, analysis, synthesis, deduction, formal legal method, comparative legal. Dialectics allowed us to push away from general theoretical ideas and determine the place of justice in law. Analysis and synthesis made it possible to identify problems of legislation and judicial practice in implementation of the principle of justice, as well as give it a definition. The use of the formal legal method in the study made it possible to describe and generalize the category of "justice". The comparative legal method made it possible to compare the legislation of the two countries, to identify similarities and differences between them.

\section{Results}

The legal expression of the requirement of justice is contained in the Rome Convention on the Protection of Human Rights and Fundamental Freedoms of 1950 (hereinafter referred to as the Convention), including in relation to the activities of the court. So, Art. 6 establishes that everyone, in case of a dispute over civil rights and obligations or any criminal charge, has the right to a fair and public hearing within a reasonable time by an independent and impartial court established by law, and Art. 41 secures the right to fair compensation. Russia and France are parties to this convention. France actively participated in development of the Convention and signed it among the first. However, France ratified this document quite late, in 1974, France recognized the right to individual appeal and compulsory jurisdiction of the European Court of Human Rights only in 1981 [3]. The Russian Federation ratified the Convention on March 30, 1998.

The generally recognized principles and norms of international law and international treaties are an integral part of the legal systems of Russia and France. The right to a fair trial, enshrined at the level of an international convention, obliges the national legislators to perceive it as a valid value, and the judiciary to form practice in development of this institution [4]. The question arises, how the conventional principle of justice is reflected in the norms of branches of law and in the acts of law enforcement in Russia and France.

The French Constitution of October 4, 1958 mentions justice in Art. 4. It states that "the law guarantees pluralistic expression of opinions and fair participation of parties and political associations in the democratic life of the Nation." The Constitution of the Russian Federation mentions justice in its preamble "honoring the memory of the ancestors who conveyed to us love and respect for the Fatherland, faith in goodness and justice."

In the French Civil Code (Napoleon's Code) of 03/21/1804, the term "justice" is found in Art. 270, p. 545, Art. 565, Art. 815-13, Art. 1135, Art. 1579 - "fair reparation", "natural justice", "rules of justice". The reform of French contract law (ordinance of February 10, 2016) allowed to strengthen flexibility of the contractual mechanism as well as contractual justice. As Remy Cabriac, a professor at the University of Montpellier, notes, the essence of the reform was to adapt the law to new social realities and new contractual relations, and the desire for contractual justice is a red thread through his many short stories, for example, the restoration of contractual balance in favor of an economically weaker (or considered to be such ) side [5].

The Civil Code of the Russian Federation (hereinafter referred to as the Civil Code of the Russian Federation) mentions justice in paragraph 2 of Art. 5 "if it is impossible to use an analogy of the law, the rights and obligations of the parties are determined on the basis of the general principles and meaning of civil law (analogy of law) and requirements of good faith, reasonableness and justice." It follows from this article that the application of these categories to resolve a disputed legal relationship is subsidiary in case that there is no legal norm that directly regulates this legal relationship or a norm regulating similar 
relations (analogy of the law). However, justice is not only a subsidiary category. As O.I. Tsibulskaya, notes, the principle of justice has a normative and evaluative nature, is embedded in the very content of the law and is embodied in rights and obligations [6].

From the standpoint of civil liability justice is understood as a representation of compliance with social ideals (parameters) of distribution of losses, other adverse consequences between participants in the legal relationship in connection with nonperformance or improper performance of the contract, harm, dishonest behavior, etc. [7]. So, paragraph 5 of Art. 393 of the Civil Code of the Russian Federation establishes the duty of a judge to independently determine the amount of losses when other circumstances are proved. As noted by S.L. Degtyarev, the need to comply with the principle of justice and proportionality of liability by the court in determining the amount of losses is nothing more than a manifestation of the general principle, the principle of full compensation for losses established by paragraph 1 of Art. 15 of the Civil Code of the Russian Federation, which declares that it is necessary to remember that according to this principle the victim has the right to demand full compensation for losses, but does not have the right to demand more than was lost [8].

Thus, despite the absence of a formal expression of justice as a principle, its "invisible" presence in the provisions of the laws of Russia and France is aimed at achieving fair legal regulation that reflects the laws of social development and the needs of society.

In the French Criminal Code, the principle of justice is formulated in Art. 132-24 (chapter "Punishment regime"): "the court imposes a punishment and determines the regime for its execution, depending on the circumstances of criminal act and identity of the performer. In imposing a fine, the court determines its size, taking into account the income and expenses of the perpetrator." This principle expresses requirement of individualization and the amount of punishment, is also characteristic of Russian criminal law (principle of justice, art. 6, part 3 of art. 60 of the Criminal Code of the Russian Federation (hereinafter referred to as the Criminal Code of the Russian Federation).

Legal consolidation of the principle of justice received in Art. 6 of the Criminal Code, which established that punishment and other measures of a criminal law nature applied to the person who committed the crime must be fair; they must correspond to the nature and degree of public danger of the crime, the circumstances of its commission and the identity of the perpetrator. Also paragraph 3 of Art. 43 of the Criminal Code of the Russian Federation indicates "restoration of social justice", and paragraph 1 of Art. 60 indicates "fair punishment". The concept of "justice" is also found in the norms of a number of articles of the Code of Criminal Procedure of the Russian Federation (hereinafter referred to as the Code of Criminal Procedure), in particular in paragraph 2 of Article 6, paragraph 4 of article 226.9, Art. 297, Art. 332, Art. 389.9, Art. 389.28 - "fair punishment", "fair sentence", etc.

The Arbitration Procedure Code of the Russian Federation (hereinafter referred to as the Arbitration Procedure Code of the Russian Federation) includes such phrases as "fair public trial" (paragraph 3 of article 2, paragraph 1. of article 308.10), "subject to the requirements of reasonableness and justice" (paragraph . 2 Article 97), "on the basis of the principles of justice, reasonableness and inadmissibility" (paragraph 4 of Article 174).

The Civil Procedural Code of the Russian Federation (hereinafter referred to as the Code of Civil Procedure of the Russian Federation) mentions the term justice in two articles in the context of a "fair trial" (paragraph 3 of article 206 and article 391.11), in particular, "the court, at the request of the plaintiff, is entitled to award a sum of money in its favor to be recovered from the defendant in case of non-execution of a judicial act, in an amount determined by the court on the basis of the principles of fairness, proportionality and inadmissibility of profit from illegal or unfair behavior (Clause 3, Article 206, this clause was introduced by the Federal Law on 03.08.2018 N 34). 
In the process of working on the concept of the Unified Code of Civil Procedure, it was proposed to consolidate the principle of justice in it. The developers of the project were guided by the recommendations of the Constitutional Court of the Russian Federation and the European Court of Human Rights. This proposal caused heated discussions among jurists. Some lawyers believed that such recommendations to introduce a new principle of the branch of law are clearly not enough. And they noted earlier the need to address a number of important questions about the scope of its action, about the subjects it is designed on, about the content, about guarantees of implementation [9].

Thus, a review of theoretical views on the category of justice and the results of monitoring the legislation of the two countries led to the conclusion that there is an ambiguous understanding of its essence and content in law. The episodic presence of the category of justice in the legislation of Russia and France is noted, which, instead of clarity and unambiguity, generates more legal uncertainty. Such a problem is common to all branches of law of the states under consideration; their relevance is significantly increasing in the light of changing social relations.

Let us turn to judicial practice, it reflects the implementation of the principle of justice in civil cases. Fair justice refers to fundamental rights, providing each entity with the effective restoration of its violated rights. In this regard, requirement of fairness should cover the entire trial.

In procedural legislation, guidelines for judicial practice, both in Russia and in France, are defined quite clearly: justice is ensured by its accessibility, correct establishment of the actual circumstances of the case, their correct legal assessment, correct interpretation of the applicable norm, which always applies in the system of other norms. This is possible provided that the legal procedures for the consideration of the case, in particular the procedural time limits, as well as the democratic principles of legal proceedings, and above all its implementation by an impartial and independent court on the basis of the adversarial and equal rights of the parties, are observed [10] (post. ECHR of 24.04.2003 in the case "Yvonon vs. France" No. 44962/98, amended on May 15, 2007 in the case "Dolgonosov vs. Russia" No. 74691/01).

\section{Discussion}

However, as Andrei Yegorov noted in his speech on August 5, 2014, the courts referred to the principle of justice in approximately 77,000 judicial acts, and to honesty in 15,000. The author notes that there are still very few scientific works in Russian civil engineering explaining the essence of the principle of justice [11].

The ambiguity of understanding and interpretation of justice is inherent in the Constitutional Court of the Russian Federation. So, according to V.A. Wipman, the analysis of judicial acts confirms the infinite number of understandings of justice used by judges in making decisions, as well as significant subjectivity in assessing certain circumstances of cases through the prism of justice. Judges sometimes use this term only to enhance the significance of their decision, the author believes, and the use of this category does not carry any semantic load and creates even greater legal uncertainty. He notes that such acts as the "constitutional principle of justice", "the requirement of justice", "the principle of justice", "the general principle of justice", and "social justice" are found in acts of the Constitutional Court of the Russian Federation [1]. And as the author rightly notes, the Constitutional Court is responsible for the resulting legal uncertainty in this matter, since the lack of a single, namely constitutional and legal approach entails confusion in legal understanding of the concept of "justice" [12]. 


\section{Conclusion}

1. Despite the absence of a formal expression of justice as a principle, its "invisible" presence in provisions of the laws of Russia and France is obvious. The single result is aimed at achieving fair legal regulation that reflects the laws of social development and the needs of society, which, in fact, is the social essence of legal regulation.

2. Review of theoretical views on the category of "justice" and the results of monitoring the legislation of the two countries led to the conclusion about an ambiguous understanding of its essence and content in law. There is an occasional mention of justice in the legislation of Russia and France, which, instead of clarity and unambiguity, generates more legal uncertainty. Such a issue is common to all branches of law of the states under consideration.

3. An unequivocal understanding of the essence of the principle of justice as a legal category has not developed either in the theory of law or in the law enforcement practice of Russia and France. This leads to a persistent distortion of understanding and a different interpretation of justice, and hinders effective administration of justice and achievement of the goal of legal proceedings namely protection and restoration of violated civil rights.

4. Justice is seen as a universal category, covering the regulatory norms of the law as well as allowing the court to make a fair decision depending on specific circumstances of the case in order to achieve a balance of interests of the participants in the process by interpreting and clarifying the law, and in some cases by creating a new rule of law that allows courts to enforce the principle of justice. In this regard, it seems necessary to consolidate the concept of "justice" in the civil and civil procedural legislation of states; this will allow avoiding contradictions in law enforcement practice.

\section{References}

1. J. Rawls, Justice as honesty (2006)

2. A. Badiu, The mysterious relationship of philosophy and politics (2013)

3. M.E. Bodoine, France and the enforcement of the judgments of the European Court of Human Rights www.ksrf.ru/en/Info/Conferences/Documents/2015Boduane.doc

4. D.A. Fursov, I.V. Kharlamova, Theory of justice in a three-volume summary of civil cases ( 2009) www.sovremennoepravo.ru/

5. R. Cabriac, Reform of the French contract law http://comitasgentium.com/en

6. O.I. Tsybulovskaya, Theory of State and Law: Lecture Course

7. D.E. Bogdanov, The evolution of civil liability from the perspective of justice: a comparative legal aspect: a monograph (2015)

8. S.L. Degtyarev, The principle of justice and proportionality of liability for damages (2017)

9. V.M. Sherstyuk, Modern problems of civil and arbitration proceedings (2015)

10. G.A. Zhilin, "Problems of Accessibility and Efficiency of Justice in Arbitration and Civil Procedure", (2001) http://www.legist.ru/conf.html.

11. S.L. Vorozhevich. Econom. Li., 9 (2017)

12. V.A. Vaipan, Theory of justice: law and economics (2017) 